\title{
Western Sophiology? The "Eternal Feminine" in the Thought of Henri de Lubac
}

\author{
ANDRZEJ PERSIDOK \\ Papieski Wydział Teologiczny w Warszawie \\ jedrekpersidok@wp.pl, ORCID 0000-0002-0730-2189
}

\begin{abstract}
The study is dedicated to the Mariology and ecclesiology of Henri de Lubac. It analyzes the works in which de Lubac emphasizes the unity of these two fields of theology, referring primarily to the Fathers of the Church and to the thought of Pierre Teilhard de Chardin. This article tries to show that these are not purely historical references, but an expression of de Lubac's original reflection, which forms a coherent whole. This whole is reconstructed at the end of the article. In consequence, there might be seen a kind of "Western sophiology," a theological synthesis in which the "feminine element" plays an important role, and the central, rather than peripheral, nature of the truths of faith concerning the Mother of God and the Church becomes visible.
\end{abstract}

Keywords: sophiology, Mariology, ecclesiology, Henri de Lubac, Teilhard de Chardin, eternal feminine

One of the characteristics of twentieth-century Catholic theology seems to be her interest in the subject of the feminine. The most striking example of this is, of course, the appearance of the so-called "Feminist theology," inspired by the postulates of contemporary feminism. ${ }^{1}$ In the current of interest in femininity we can also certainly include statements by John Paul II regarding the dignity or "genius" of women and the need to rethink their role in the Church. ${ }^{2}$ In this context, it is also worth recalling the view of Scottish philosopher and theologian Fergus Kerr, who suggests that the most important breakthrough in 20th-century theology is a change in the model of thinking about God and his relationship with the world. Neoscholastics were replaced by "spousal mysticism," for which the best image of the relationship between the Creator and creation is the relationship between the Bridegroom and the bride. ${ }^{3}$ Such a model of practicing theology, on the other hand, implies the need of theological elaboration of the theme of femininity, which becomes a privileged image of creation, humanity and the Church in their relationship with God the Creator and Savior.

Loades, "Théologie féministe," 558-559.

John Paul II, Letter to Women.

Kerr, Twentieth-Century Catholic Theologians, 82-84. 
Among the main authors of this turn in theology, Kerr mentions the French Jesuit, Henri de Lubac, ${ }^{4}$ emphasizing the value of his new editions of patristic and medieval commentaries on the Song of Songs. ${ }^{5}$ As for de Lubac's own theological search, topics such as spousal relationship and femininity appear primarily in his ecclesiological works, which also contain references to Mariology. ${ }^{6}$ It can be said that the theologian from Cambrai synthesizes in them two powerful spiritual movements developing in the Church on the eve of the Second Vatican Council: the Mariological and the ecclesiological. ${ }^{7}$

In his essay on de Lubac's thought, John Milbank suggests another interesting direction of examining it in search of "spousal" and "feminine" themes. ${ }^{8}$ Namely, he points to the commentary published by him in the late 1960s on the poem of his friend and mentor, Pierre Teilhard de Chardin, entitled L'Éternel féminin, and grasping the history of creation and salvation as a cycle of transformations of the "eternal feminine," crowned with its deifying nuptials with Creator. ${ }^{9}$ Milbank is of the opinion that the theme of the "eternal feminine" taken from Teilhard de Chardin fits perfectly with de Lubac's works on the relationship of nature and grace. The English theologian even claims that when he writes about "desiderium naturale" and "eternal feminine," the author of Catholicism means one and the same thing. ${ }^{10}$

Another interesting thought of Milbank concerns the convergence of the basic intuitions of Henri de Lubac and Sergei Bulgakov, in his opinion the two greatest twentieth-century theologians. ${ }^{11}$ The latter was one of the leading representatives of sophiology, a philosophical and theological current, which saw the solution to the eternal problem of the relationship between God and creation in the biblical image of Sophia-Wisdom, God's bride who sustains the world in existence and in a passionate impulse leads it to unite with the Creator. ${ }^{12}$ In this statement one can see the suggestion that de Lubac's theology with its spousal thread, which was most strongly outlined in L'Éternel féminin, is a kind of Western sophiology - a philosophical-theological synthesis showing the unity - without confusion - of the created and the Uncreated. ${ }^{13}$

4 Kerr, Twentieth-Century Catholic Theologians, 82.

5 Kerr, Twentieth-Century Catholic Theologians, 82.

6 Kerr, Twentieth-Century Catholic Theologians, 84; as is well known, both in Greek and Latin, as well as in most modern European languages, the word "church" (Greek: ekklesia) is feminine.

7 Ratzinger, "Miejsce mariologii," 15-16.

8 Milbank, The Suspended Middle, 104-108.

9 De Lubac, L'Éternel féminin (in what follows: $E F$ ).

10 Milbank, The Suspended Middle, 105.

11 Milbank, The Suspended Middle, 104.

12 Lévy, "Sophiologie," 1343-1344; Špidlík, Myśl rosyjska, 393-421; Bułgakow, Światło wieczności, 302-333.

13 Milbank, The Suspended Middle, 105-106; a direct influence of sophiologists on young Teilhard de Chardin does not seem probable, although Antoine Arjakovsky claims that the French thinker had an opportunity to meet Berdyaev and it is there that he traces the source of "sophiological" threads in his work, Arjakovsky, "The Sophiology of Father Sergius Bulgakov," 227. 
In this study, we'd like to follow Milbank's suggestions and show how the Mariological and ecclesiological themes present in de Lubac's works combine into a coherent synthesis. In showing this synthesis, an important role will be played by the commentary on L'Éternel féminin, treated not so much as a work devoted to the thought of Teilhard de Chardin, but as an expression of the views of the author of Catholicism himself. It is in the light of L'Éternel féminin that the fragmentary references to patristic and medieval theology find their place within the whole. We see this whole as a kind of Western sophiology, pointing to the features which make it similar to the thought of such authors as Bulgakov or Soloviev. Although, unlike some of his contemporaries, ${ }^{14}$ de Lubac did not attempt to transpose the assumptions of eastern sophiology into Western theology, he was aware of the similarities here. ${ }^{15}$

In order to achieve the goal of this study, we will analyze in chronological order four works of Henri de Lubac that contain material of the highest value from the point of view of the issues raised in it: Méditation sur l'Église (1953), ${ }^{16}$ Paradoxe et mystère de l'Église (1967), ${ }^{17}$ L'Éternel féminin (1968) ${ }^{18}$ and "La maternité de l' Église" (1971). ${ }^{19}$ In the conclusion, we will try to reconstruct the "sophiological synthesis" present in them.

\section{Méditation sur l'Église (1953)}

Catholic Mariology and ecclesiology are usually treated as peripheral spheres of dogma, situated in the lowest place of the "hierarchy of truths of faith." In the ninth chapter of the Méditation sur l'Église de Lubac shows that this opinion is not correct. ${ }^{20}$ He claims that the "double mystery" of Mary and of the Church plays an important role in defending and enhancing the entire Christian Mystery: it accurately defines the part of human participation in God's work as subordinate, yet real and essential $(M E, 242)$. "What Catholic faith says about the Holy Virgin symbolically summarizes the doctrine of human cooperation in the work of Redemption, thus giving a synthesis or mother idea of the dogma of the Church" (ME, 242).

Both the mystery of the Mother of God and the mystery of the Church are focused on the possibility of human mediation in God's action, but one that does not

\footnotetext{
14 The most important attempt to create Western sophiology in the strict sense is the theology of Louis Bouyer, cf. Lemna, "Louis Bouyer's Sophiology."

15 Cf. Parts of this study concerning particular works by de Lubac.

16 De Lubac, Méditation sur l'Église (in what follows: $M E$ ).

17 De Lubac, Paradoxe et mystère de l'Église (in what follows: PME).

$18 \mathrm{EF}$.

19 De Lubac, "La maternité de l'Église" (in what follows: MT).

20 ME, 241.
} 
deny anything to Christ's only mediation (ME, 241). This is why de Lubac will be able to say that both mysteries are tied together not only by the bond of external analogy, but their bond is somehow "woven from the inside" so that they constitute "the one and the same mystery."21 Mary is the "ideal figure of the Church," her "sacrament" and "mirror"; she carries and contains in her person the entire Church. ${ }^{22}$ There is an "communication of properties" and "interpenetration" between Mary and the Church, to such an extent that the concept of "communicatio idiomatum" known from Christology could be used here. ${ }^{23}$ De Lubac, quoting ancient and modern authors, also speaks about the "mystical identity" between the Church and Mary, about their "perichoresis" 24 and about the fact that Mary is the seed, the pleroma and the perfect form of the Church. ${ }^{25}$

Such a close mystical identification of the Church and Mary is therefore primarily due to the analogous, mediating function which both play in God's plan of salvation. However, it embraces not only Mary and the Church as a whole, but also every human soul that forms part of it: "Mary is the first beloved, but in her, every holy soul is endowed with equal love, and above all the whole Church, of which she is $<$ form >." ${ }^{26}$ Both the Church and the particular souls that belong to her have a "Marian structure." What happened in the Mother of God in a perfect and unique way, is prolonged and developed in individual members of the Church: "The mystery of the Church is not so much a prefigured copy of the mystery of Mary, but rather its continuation." ${ }^{27}$

Since the mystery of Mary, the Church and the human soul is in fact one and the same mystery of active cooperation with grace, although realized on three different levels, how do the particular levels relate to each other? Drawing mainly on theologians of the non-scholastic Middle Ages, de Lubac puts this triple relationship in the following way: what refers to the church generaliter (in general), refers to every soul singulariter (in the sense of singularity - because in every soul takes place what took place in the Church), while to Mary specialiter (in the sense of uniqueness of the highest degree).$^{28} \mathrm{He}$ notes that the relationship between these three modes of realization can be understood in two different ways. On the one hand, the generaliter (or universaliter) integrates the other two, because "universality includes all cases and because Mary is a member of the Church, just like each of us." On the other hand, the generaliter gives way to the specialiter, the "special" case, the only "universal con-

\author{
$M E, 243$. \\ $M E, 245$. \\ $M E, 251$. \\ $M E, 251,255$. \\ ME, 259. \\ $M E, 279$. \\ ME, 280. \\ ME, 263-264.
}


crete" which contains the sum of perfections of all other members. ${ }^{29}$ What constitutes the essence of the Church is not some formal principle, a purely structural potentiality, but an extension - by virtue of "mystical analogy" or "perichoresis" - of Mary's only and unique fiat to the whole Church and to all its members. Therefore, Mary, a concrete person of universal significance, at the same time totally subordinate to Christ and freely cooperating with Him, may be called "universal creation." 30

Emphasizing the both concrete and the universal character of Mary, the Mother of God, is closely related to theme of "concrete universal" ("universale concretum"), very important for de Lubac, which we will dwell on later in this study. It is worth noting here that the basis for the "mystical identification" of Mary, the Church and the human soul is the attitude taken by creation towards God's creative and salutary action. This attitude is completely receptive, but by no means passive. As Gérard Philips explains, there is a clear difference between receptivity and passivity. While objects allow themselves to be manipulated in complete passivity, the personal entities are invited by God to "receive," that is, to accept His action in freedom. In this case, passivity would mean denial of action, deaf resistance and servility, while, according to Christian spiritual tradition, grace is something that liberates. ${ }^{31}$ To be authentically receptive, a person must act, open their soul and cooperate. This concept of 'active receptivity', divine-human synergy, boldly present in de Lubac's theological vision, ${ }^{32}$ forms the basis of Catholic Mariology, ecclesiology and anthropology. ${ }^{33}$ It is no wonder then that Protestant theologians, who assume that only God can play an active role in His relation towards creatures, oppose the Catholic view on all three of these theological issues, seeing in the Mother of God the "principle, prototype and summary of a human creature cooperating in its salvation." ${ }^{34}$ Karl Barth, cited by de Lubac, rightly remarked that Mariology, ecclesiology and anthropology, closely related to each other, are by no means peripheral areas of Catholic doctrine; they are, in fact, the "center of Catholicism" 35 and it is by them that "all principal Catholic positions" are determined. ${ }^{36}$ In Marian dogma, in Church ecclesiology and in the Catholic vision of man - quite the opposite to the Protestantism - the human addressee of God's gift of grace does not expect him passively, but actively desires and receives him. ${ }^{37}$ Grace does not need passivity, but liberates to cooperation and synergy. ${ }^{38}$

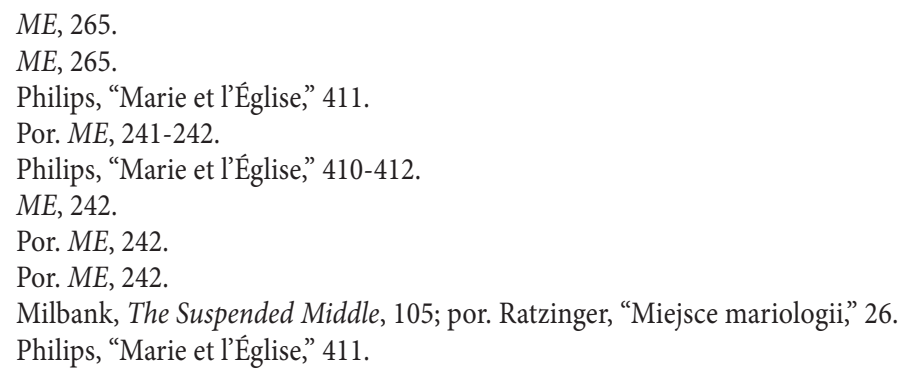




\section{Paradoxe et mystère de l'Église (1967)}

Another work by de Lubac, in which the subject of the relationship between Mariology, ecclesiology and anthropology appears, is Paradoxe et mystère de l'Église, a brief commentary to the conciliar Dogmatic Constitution on the Church, published in 1967. In the third chapter of this work de Lubac deals with the influence of patristic thought on the content of the document. Among the topics with a clear patristic inspiration, he points to the close relationship between the Church and the Virgin Mary, emphasized by the Constitution.

According to de Lubac, in the oldest theological tradition, ecclesiology and Mariology were perceived as so closely related that they basically constituted one thing. Therefore, parallelism between Mary and the Church should not be treated as a side issue, but "one of the most important features of the Catholic conception." ${ }^{39}$ Recreating the traditional vision of the relationship between Mary and the Church, which found its place in the Lumen gentium constitution, de Lubac describes it in terms of "model" and "reproduction." ${ }^{40}$ Virgin Mary is in the Church a "model of receptivity in front of the waves of God's grace," and this receptivity is closely related to the theme of motherhood. ${ }^{41}$

Later in his study, the author of Catholicism quotes various modern theologians who emphasized the unity of Mariology and ecclesiology. In this way, he somehow defends the conciliar ecclesiology in front of the possible accusation of drawing on the symbolic mode of thinking proper to the Fathers, which is long overdue. De Lubac strongly emphasizes that the subjects treated here are not more difficult to accept today than in the times of Ambrose or Augustine. ${ }^{42}$ One of the theologians cited is Hans Urs von Balthasar, who points to Mary as the model of receiving the Word. In his opinion, the Marian mystery allows Catholic thinking to defend itself against two dangers: on the one hand, against treating the Word as something completely external to man, and on the other, against confusing it with human words ${ }^{43}$ It is noteworthy that Mary's exemplary character refers in the first place to the Church as such, but in Balthasar's words a basic statement about Catholic anthropology is also implicitly contained - namely, the ability of human nature to cooperate with grace. The same theologian in his Theology of History states that Mary is the living center of the Church, as she is the one in which "receptivity" is perfectly realized, and for this reason she can be identified with the Church. ${ }^{44}$

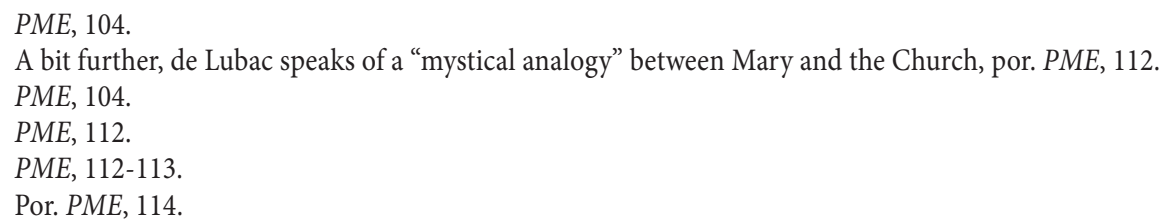


De Lubac dedicates much more space to another Catholic thinker of his time, Pierre Teilhard de Chardin. ${ }^{45}$ He finds in his thought the "absence of distinction" or "mystical identification" between Mary and the Church. ${ }^{46}$ He quotes an extensive fragment of Teilhard's poem "L'Éternel féminin," which describes "the ascending stages of the eternal feminine, which in the form of biblical (and liturgical) Wisdom addresses its words to the human beings:" ${ }^{77}$

"Placed between God and the earth, as a terrain that attracts both, I force them to a mutual and passionate encounter (...) I am the Church, the bride of Christ. I am the Virgin Mary, Mother of all people." ${ }^{48}$

As de Lubac notes, both Balthasar and Teilhard de Chardin refer to the biblical symbol of God's Wisdom to show the nature of the relationship between Mary and the Church. The theologian sees in this appeal an echo of patristics and indicates that the Western Fathers more often applied the sapiential texts to Mary, while in the Eastern patristics the symbol of Wisdom was associated rather with the Church. ${ }^{49}$ Also, he doesn't forget about the similarities between this theme and the Eastern sophiology: in the footnote, he refers to the book by Louis Bouyer, who is the author of the boldest attempt of sophiological speculation in modern Western theology..$^{50}$ Perhaps it is the sophiology, which combines Christology, Mariology and ecclesiology, that he refers to as the level of meaning of the symbol of Wisdom, which, although not mentioned in Lumen Gentium, seems worth considering. ${ }^{51}$

As can be seen, in Méditation sur l'Église and in the Paradoxe et mystère de l'Église de Lubac combines not two, but three issues: in the first place he reflects on the relationship between ecclesiology and Mariology, but theological anthropology is also present in the background - specifically the Catholic vision of cooperation between human nature and grace. His Mariology and ecclesiology express in dogmatic terms the same thing that he expressed in the more philosophical language as the relationship of nature and the supernatural: Mary, "full of grace" and handmaid of the Lord who freely responds to God's plan, is not only a model of the Church, but also of human nature endowed with "a natural desire to see God" and thus open to the supernatural complement. Not without significance is the fact that the Church, like Mary, is presented in his thought by means of female and personal symbols. Thanks to this, the formal binomial Creator-creation can be translated into the personal lan-

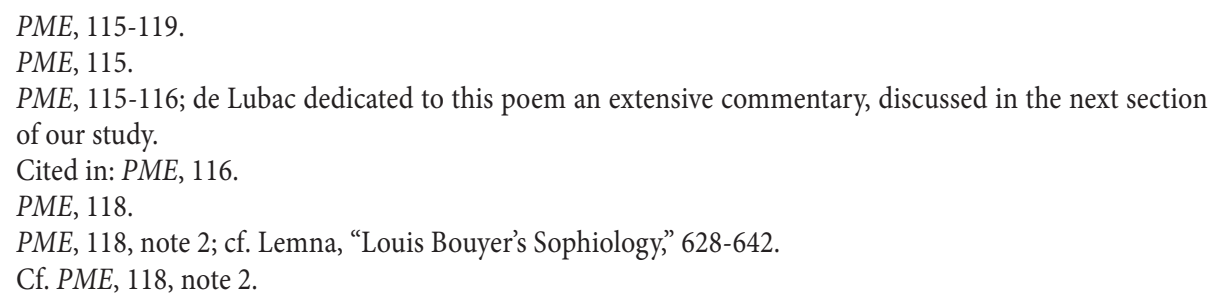


guage as the relationship between the Bridegroom and the bride, where the latter is simultaneously Mary, the Church and each human soul.

The symbolism of the Bridegroom and the bride, ubiquitous in the Bible, makes of the woman a model of thinking about human nature in general; she "is the mouth which, in the name of all humanity, utters the humble fiat of God's servant as a response to the creative Fiat of the heavenly Father." 52 As Joseph Ratzinger noted, the appreciation of the "female line" present in the history of salvation, going from Eve, through the wives of patriarchs and figures such as Esther or Ruth up to Sofia-God's Wisdom, is, next to emphasizing the receptive-active role of creation in meeting with the Creator, a feature that distinguishes Catholic synthesis from the Protestant versions of Christianity. ${ }^{53}$

\section{L'Éternel féminin (1968)}

In two of de Lubac's works discussed above, issues associated with broadly understood sophiology are located within ecclesiology and Mariology, and indirectly also concern theological anthropology. They are based primarily on the thought of the Church Fathers, who, within their holistic vision of reality, eagerly pointed to the mystical identity of Mary, the Church and the human soul. Inspired in them, de Lubac was aware, however, that in today's context it is impossible to imitate exactly their style of thinking. Hence, as we have already mentioned, in Paradoxe et mystère de l'Église, he tried to point out modern thinkers who come to conclusions similar to those of the patristic thought. ${ }^{54}$

One of them is Pierre Teilhard de Chardin, with whom de Lubac was friends and from whose thought he drew inspiration at various stages of his creative life. ${ }^{55}$ Already in the Paradoxe et mystère de l'Église, the French theologian referred to Teilhard's poem entitled "L'Éternel féminin." ${ }^{56}$ It is to this poem that he dedicated one of the most peculiar works in his opus: a commentary bearing exactly the same title. The peculiarity of this work can be summarized as follows: it is a long (more than two hundred pages) and insightful commentary on Teilhard de Chardin's early work,

\footnotetext{
52 Evdokimov, La femme et le salut du monde, 152; cf. Nicolas, "La doctrine mariale," 361.

53 Ratzinger, "Znak niewiasty," 37.

54 Cf. PME, 112-119.

55 The important role which Teilhard de Chardin played in the development of de Lubac's thought can be seen from the bibliographic indexes in the works of the latter, beginning with Catholicism. It should be noted, however, that this was not an uncritical reception - the later cardinal critically assessed e.g. the conviction of the senior Jesuit about his own innovativeness, seeing in his bold cosmo-theological vision a rather new way of expressing ideas already known to the Fathers of the Church, cf. de Lubac, La pensée religieuse, 268; cf. Wagner, Henri de Lubac, 180-182. 
published equally fifty years after its creation. ${ }^{57}$ Although in the eyes of its author this early poem does not seem to have much significance, de Lubac devoted to it more space than to any other of Teilhard's writings.

Our thesis is the following: de Lubac, writing his L'Éternel féminin not so much wanted to perform the exhaustive exegesis of his confrere's poem, but rather to develop on its ground his own original thought. ${ }^{58}$ This fits perfectly in the general manner of his theological activity - often, instead of expressing his own ideas himself, he allows others to express them instead. ${ }^{59}$ If we follow such a reading of de Lubac's work in question, then we will be able to treat the vision of transformations of the "eternal feminine" presented in it as a kind of "sophiological synthesis," constituting a metaphysical frame for fragmentary threads scattered in the ecclesiological works of the French theologian.

Teilhard de Chardin's poem has a form of a long monologue of a mysterious female figure, initially anonymous, but then becoming more and more concrete: Dante's Beatrice, Virgin hidden behind the veil, and finally the Mother of God. She presents herself, showing her role in God's plan since the beginning of the world. De Chardin consciously stylizes her statement on a monologue of Divine Wisdom from the Old Testament sapiential books. This figure is the "eternal feminine," a feminine element inscribed in the constitution of the universe itself. ${ }^{60}$ For Teilhard de Chardin, but also for de Lubac, it is identified with the receptive and unifying side of reality. ${ }^{61}$ It is a great, secret force through which everything exists, everything connects, fertilizes, rises and is organized. ${ }^{62}$ The "eternal feminine" performs a kind of mediating function between the Creator and creation; she says about herself that she is "a region of mutual attraction between God and the earth." ${ }^{63}$ At various stages of the process of the evolution it takes more and more complex forms: beginning from a simple cosmic force, through the phenomenon of human love, to the supernatural reality of the Church and Mary as its archetype. ${ }^{64}$

The "transformations of the female element" are the content of the poem "L'Éternel Féminin." They lead up from the inanimate-universal to the concrete personification; from the simplest form of "cosmic attraction," through the reality of human love to the mysterious Beatrix, the "Veil-covered Virgin"; behind the veil is Mary, the one

\footnotetext{
57 About the circumstances in which this work of de Lubac was written: cf. de Lubac, Mémoire, 108.

58 This argument agrees with the way EF is treated in John Milbank's work mentioned in the introduction, cf. Milbank, The Suspended Middle, 105.

59 Cf. Kerr, Twentieth-Century Catholic Theologians, 82.

60 About the "eternal feminine" in the European thought, cf. Balthasar, Herrlichkeit, 459-462; about the origin of the notion of the "eternal feminine," cf. EF, 53.

$61 E F, 54$.

$62 E F, 33$.

$63 E F, 37$.

$64 E F, 35$.
} 
in whose womb the Incarnation of the Word took place - the Word "lured to earth by a miracle of which He is the Creator." ${ }^{65}$

Commenting on his confrere's poetic text, de Lubac is aware of the similarities between the cosmic-theological vision contained in it and Eastern Christian sophiological speculations. In the poem, thus, "eternal feminine" is clearly identified with the biblical figure of "God's Wisdom," "Active Wisdom, collaborator of God's work." The theologian, however, emphasizes that "Sophia-Wisdom" - according to Teilhard, identical with the "eternal feminine element" - should not be treated as a hypostasis in the style of Sergei Bulgakov's sophiology. ${ }^{67}$ The "eternal feminine element" is not, as in Bulgakov, something between God and creation, but is definitely situated on the side of creation. Fully unveiled in the Mother of God, it is woven into the history of the world and leads from the beginning to the unification of creation with the Creator.

To justify the treatment of such different realities as the impersonal cosmic force and the person of the Virgin Mary as stages of one process, de Lubac introduces the concept of "dynamic analogy," which, in his opinion, is one of the fundamental ideas of Teilhard's vision of the universe. It is worth noting that the very concept of analogy, one of the key concepts in classical metaphysics, appears often in two different, albeit related, contexts. ${ }^{6}$ The first of these is the question about the possibility of analogous reference of human concepts about God. ${ }^{69}$ The second context concerns the relationships between the various entities that form the world as a whole: pointing to their analogous unity, the theory of analogy emphasizes that, although diverse, they do not constitute a chaotic set of unrelated monads, but form an internally related whole; therefore, being is not, in a strict sense, equivocal, but analogous. ${ }^{70}$

The theme of "dynamic analogy" discussed by de Lubac is situated in the latter context. However, while in classical metaphysics the analogical unity of the world was considered in a static manner, what Teilhard does is translating it into the evolutionary vision of the universe $(E F, 122-123) .{ }^{71}$ The created world consists of different levels of being, analogously related to each other, but this diversity and connection concerns not only the various elements that co-exist in a determined moment of time, but also the various stages of its development throughout the temporal process. Teilhard de Chardin, followed here by de Lubac, comprehends this development as the act of transcending successive thresholds, where each subsequent, in continuity

\footnotetext{
$65 E F, 170$.

$66 \quad E F, 155$.

$67 \quad E F, 156$.

68 Cf. Shanley, The Thomist Tradition, 49-50.

69 Cf. Shanley, The Thomist Tradition, 49; this aspect of the issue of the "analogy of being" received its most famous treatment in 20th century in the work of the German Jesuit Erich Przywara, cf. Raczyński-Rożek, „Analogia Entis," 215-231.

70 Cf. Shanley, The Thomist Tradition, 50.

71 De Lubac speaks of a "projection of Aristotelianism on the evolutionist plan" $(E F, 124)$.
} 
with the previous ones, is at the same time a radical novelty: "the completely new slips into the heart of repetition." 72 In this process, which is a "horizontal projection of the vertical system of degrees of being," one can see the analogy in the strict sense of the word: successive entities connected by a bond of origin, where each subsequent one is simultaneously both completely similar to the previous one and completely different from it - "totum, non totaliter," as a scholastic adagium says. ${ }^{73}$ The "eternal feminine" constitutes such a "line of reality" ("ligne de réalité"74), which consists of similarly interrelated subsequent stages of the "female element" that permeates all reality, beginning from its simplest elements.

Consecutive manifestations of the "eternal feminine:" the cosmic unifying force, the human love, the Virgin Mary, the Church, do not constitute a completely equivocal multiplicity. In Teilhard's poem, they are clearly connected by the mysterious bond of "dynamic analogy." De Lubac seems to accept this vision as his own, hence it perfectly harmonizes with one of the main goals of his theology, which is to show the unity of God's plan realized in history, from creation up to the eschatological fulfillment. ${ }^{75}$ However, one-sided emphasis on the unity of subsequent manifestations of "eternal feminine" could expose the author to the accusation of insufficiently emphasizing the differences between them. Given the poetic form in which Teilhard's metaphysical vision has been expressed, more than one reader would probably be inclined to see both in the mysterious Beatrix and in the Virgin Mary herself the mere allegories of the cosmic force of female attraction - blind, unconscious, omnipresent dynamism. In this case, the embodiment of the universal dynamism in concrete female figures would be a mere literary operation concealing a fundamentally homogeneous, materialistic vision of reality. ${ }^{76}$

However, as de Lubac points out, in Teilhard de Chardin the relationship between the universal and the personal is seen quite differently: it is not that the "universal" is dressed in "personal" garments to become easier for us to absorb in the form of a myth, but rather the "personal" becomes "universal" as it becomes fully realized, because "universality is the prerogative of what is in the highest degree personal." 77 According to this principle, God, because he is the Being in the highest sense, is the most personal and "personifying," and Christ remains fully a person even in his cosmic influence. ${ }^{78}$

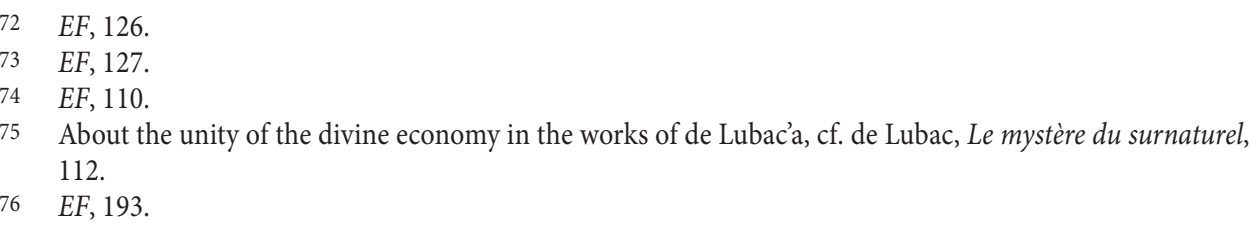


At the root of this claim about the relationship between universality and personality lies the fundamental law of Christian metaphysics: "universality" and "concreteness" (without which "personality" cannot be thought) are not two contradictory dimensions of reality that cannot characterize the same being. In L'Éternel féminin (as in other of his works) de Lubac refers to the idea of "concrete universal," present in the Western philosophical and theological tradition. For pure philosophy it remains an impossible postulate, while in theology it is of fundamental importance, above all for the right understanding of the dogma of the Incarnation. ${ }^{79}$ God, the most universal as the Creator and foundation of all that exist, is at the same time eminently personal. ${ }^{80}$ A Christian recognizes this God in Christ, God-Man. ${ }^{81}$ As the "universale concretum," Christ is not a general principle personified by man, but authentically and irrevocably, a person. ${ }^{82}$

Although the simultaneous attribution of universality and concrete personality refers primarily to God and to Christ, God-Man, such attribution can also be applied in an analogous way to Mary and her role in the history of salvation. Here, de Lubac finds the key to the understanding of Mary's place in Teilhard's vision of the "eternal feminine." If Teilhard de Chardin "attributes to the Virgin, seen in her most specific, unique and internal personality, a kind of universality analogous to that which he recognizes in Christ," ${ }^{33}$ the basis for this attribution is Christological. As God incarnate, God-man, Christ is the "universal bond" through which all creation unites itself with God. ${ }^{84}$ As a "universal bond," however, he is also irrevocably Jesus, a concrete being born of the Virgin..$^{85}$ By virtue of this maternal relationship, Mary is also united with the "personifying" and "universalizing" work of her Son. She performs in the Mystical Body a "mysterious complementary function" to the action of Christ; for each of us she is a necessary "introducer" ("introductrice"). ${ }^{86}$ As "the introducer," Mary "in the likeness of Christ, with whom she is totally united" is really universal (<universelle>); "with him, replevit omnia." 87

De Lubac took the notion from Maurice Blondel, although it is also present in the writings of Teilhard de Chardin himself. Another thinker who devoted much attention to the issue of "concrete universal" was Hans Urs von Balthasar, whom de Lubac quotes extensively, cf. EF, 198-199. A synthetic overview of the whole issue can be found in: Pié-Ninot, La teología fundamental, 274-296. About "concrete ontology" as a fundament of Christian worldview, cf. de Lubac, Le mystère du surnaturel, 90-95.

$81 \quad E F, 198$.

$82 E F, 199$.

83 EF, 205.

$84 E F, 202$.

$85 E F, 202$.

86 EF, 206; a bit further, de Lubac recalls a similar idea expressed by Dante in the Divine Comedy: when Dante enters Paradise, Saint Bernard orders him to look at Virgin Mary's face as the radiance of her face can make him ready to see Christ, cf. EF, 214.

87 This idea of the Virgin Mary "pervading everything" appears in the context of the analogy between the Ascension of Christ and the Assumption of Mary, cf. EF, 207. 
Explaining the idea of Teilhard de Chardin, the French theologian states that the position of the Mother of God as the culmination of the process of transformation of the "eternal feminine" does not mean her "dissolving" in an anonymous universality, but rather showing the "secret of femininity" as "contained in [the Virgin Mary] and receiving from her its highest importance." ${ }^{88}$ It is not the abstract principle that is personified in the Virgin, but the Virgin, existing in her uniqueness ("singularité"), becomes universal through the omnipresent principle. ${ }^{89} \mathrm{It}$ is, therefore, an inverted symbolic relation: it is not Mary who is the fulfilled symbol of the "eternal feminine element," but it is the "eternal feminine element" that should be understood, in its purest essence, as the symbol of the Mother of God. ${ }^{90}$ Her relationship with the cosmic receptive-unifying force is a "reversed symbolism," in which a particular person constitutes the truth of the general process, and not the other way round.

The Virgin Mary is the fulfillment of the cycle of transformations of the "eternal feminine" and the "concrete universal" which provides content to the whole process. ${ }^{91}$ However, she is not its end. Like her Son, she identifies with the Church, or, in the right order, the Church identifies with the Virgin (cf. EF, 214). ${ }^{92}$ De Lubac, drawing on Jean-Jacques Olier, calls Mary "a universal creation," inviting the reader to contemplate in her "the sum of perfections which are spread throughout all members of the Church." ${ }^{93}$ He also refers to Paul Claudel, who saw in Mary the "form" of the Church, of the whole humanity and the whole creation. ${ }^{94}$ In this mystical identification, the Church is not seen as a purely contingent historical phenomenon, but - like Mary, its archetype - as the "<component> of the universe," the "unifying side of the Real." ${ }^{95}$ In him, the final unification of creation with the Creator takes place, which, however, does not mean dissolution, but definitive confirmation in being. ${ }^{96}$ There-

\section{$88 \quad E F, 196$.}

$89 E F, 196$.

$90 \quad E F, 196$.

91 This is a different formulation of the fundamental principle of the theology of the supernatural developed by de Lubac: in the relationship of nature and grace it is not grace that becomes understandable from the point of view of nature but only nature becomes fully understood in the light of grace; the goal explains the beginning, not the other way around, cf. de Lubac, Le mystère du surnaturel, 128.

92 De Lubac emphasizes that this is not an original idea of Teilhard de Chardin but rather a "reviving of the old patristic and medieval motif."

93 Apart from this 17th Century spiritual author, de Lubac points to the clear analogies between the Teilhard de Chardin's vision and Die Ewige Frau, written by Gertrude von le Fort, cf. EF, 203.

94 Another, much older example of theology connecting Mary, the human soul and the Church is the spiritual interpretation of the motif of Mary, the Ark of the Covenant, present in Saint Bonaventure, cf. EF, 204.

95 As de Lubac has repeatedly emphasized, the Church, in its full development, will be identical with the world fully reconciled with itself and with God, cf. PME, 55.

96 As Ratzinger explains, it is the Marian vision of the Church that protects us from its understanding in the spirit of Christomonism. The Church is indeed the Body of Christ, but only "in the spiritual tension of love in which the marital mystery of Adam and Eve is realized, and therefore in the dynamism of unity that does not remove separateness" (Ratzinger, "Miejsce mariologii," 22). 
fore, the "feminine element" in creation, expressing its openness to the divinizing grace, is truly the "eternal feminine" that will not disappear even in the eschatological fulfillment of the universe:

In blessed contemplation, in this union of heaven and earth, prepared from the beginning of the world, inaugurated in the womb of the Virgin and now fulfilled, with only a moment of loosening the tension, which causes the elect to be completely absorbed in God, there could be seen, <on the surface of God Fire>, the playing image of Her, in whom is summarized the <always alive series of successively traversed attractions, due to which elements of the Spirit converged from the very limits of Nothingness and united through love>. This image, this bond, this unity of the series, is the eternal feminine. ${ }^{97}$

\section{4. "La maternité de l'Église" (1971)}

In the multi-threaded metaphysical vision that de Lubac reconstructs on the basis of the poem "L'Éternel Féminin" of Teilhard de Chardin, the close bond between Mary and the Church is emphasized. It is from Mary, as its model, that the Church derives the power of its universal, unifying influence. This bond also implies the concrete and personal character of the Church, hence its archetype and "form" is the person of the Mother of the Lord, and not some abstract structure. In La maternité de l' Église, the last of a series of works discussed here, de Lubac focuses precisely on showing its personal and concrete nature.

As in other texts, here too de Lubac seeks inspiration primarily in patristics, but without limiting himself to this era. ${ }^{98} \mathrm{He}$ points out that what has become a fulfilled reality in the Church has already been announced in the myths, although in a confused way: as in pagan religions, the Great Mother "contained all the cosmos" and all life "came out of her womb and returned to it," so now the whole cosmos is contained in the Church, but already transformed, renewed, converted. ${ }^{99}$

The motherhood of the Church is a reality that has its archetype in Mary, the Mother of God. The Church, similarly to Mary, "conceives the Word in flawless faith, gives birth to It in a spirit free from all corruption, carries It in a soul protected by grace from on high." Just as Mary gave birth to the only Son, the Church gives birth to many children who in this only Son become one. ${ }^{100}$ The Church-Mother through birth continually "gathers God's scattered children into one."101

\footnotetext{
$97 \quad E F, 176-177$.

$98 \quad M T, 153$.

$99 M T, 152$.

100 MT, 153-154.

$101 M T, 161$.
} 
Although in the image of the Church as a Mother the particular faithful appear above all as recipients of the Church's activity, de Lubac does not ignore the second, more internal aspect: since the Church lives in its members, each of them also actively participates in the realization of church motherhood. Therefore, ultimately, this mystery has two aspects, because it is "one indivisible motherhood of everyone in respect of each one and motherhood of each one in respect of everyone." ${ }^{102} \mathrm{~A}$ Christian submits to the action of the Church-Mother, but by the same act of submission, he allows the God's Word to be born and grow in himself. He receives the Word from the Mother Church, but as a participant in this motherhood, he also contributes to its further fruiting. ${ }^{103}$ Again, the act of accepting the gift of grace appears not as passivity, but as liberation to active synergy. ${ }^{104}$

The theologian does not forget that the Church has its own specific structure. That is why he emphasizes that "the maternal role of everyone and everyone, both in relation to the Word of God in a particular soul and in relation to the whole community" can be fulfilled only thanks to the fatherly role exercised by its ordained ministers. ${ }^{105}$ However, priority is given to the maternal aspect: before it becomes an institution, community, structure, the Church is the Bride and the Mother, hence her ability to connect people between themselves and with God, respecting their personal dignity and individuality. ${ }^{106}$ As Joseph Ratzinger states, the Church is something more than a structure and an action - "in it, there lives the mystery of motherhood and spousal love that constitutes the condition of motherhood."107

However, both the maternal character of the Church and the paternal function of ministers become understandable only in the context of the totality of Christian mystery, which "is nothing other than our participation, through the grace of Christ, in God's inner life." 108 The Church is not a political structure, but a participation in the inner life of the Holy Trinity. Assembling a number of patristic testimonies, de Lubac shows that the mystery of the Mother Church is in fact the mystery of participation in the life of the Father, the Son and the Holy Spirit. ${ }^{109}$ If, according to the expression of Saint Irenaeus, the Father accomplishes the work of human salvation through his

102 MT, 172; about the two dimensions of the maternity of the Church cf. Rahner, Maria und die Kirche, 53-59.

103 MT, 170.

104 Cf. Philips, "Marie et l'Église," 411.

$105 M T, 175$; it does not mean that ministers do not participate in the Church's motherhood - for, before they become fathers in the Church, they are her children, cf. MT, 178.

106 Cf. "Even before it received its structures in Peter, the Church is already present in Mary as the Body. She is first (...) feminine and only then, in the Church ministry, will she receive a complementary male side," Balthasar, "Maryjny rys Kościoła," 124.

107 Ratzinger, "Miejsce mariologii," 21.

108 MT, 193.

109 MT, 194. 
two hands - the Son and the Holy Spirit - then, adds the theologian, these two hands of the Father "reach us through the two maternal arms of the Church."110

This pointing out of the mystery character of the Church is crucial if one wants to avoid a "worldly" view of the Church and of the relations that constitute it. According to this view, it would only be an impersonal structure of power and servitude. In this context, an important remark is provided by de Lubac: although it is not a mistake to talk about "Christianity" or "Catholicism," such way of speaking may hide from our eyes the fact that it is not an abstraction but a "life, God's own life to which we are invited." In order for us to be born into this Life, we need the Church, Catholica Mater (MT 197). ${ }^{111}$

What de Lubac writes about the "vital" - and not purely doctrinal or structural character of the Church directs the reader towards the last two chapters of his book on the motherhood of the Church, titled "impersonal world" and "Church and personal existence." In the first of these, the theologian shows how the world in which we live undergoes a progressive mechanical self-organization. Against this background, the Church is revealed as a place of personal relations, in which the social dimension is as important as each person, in its unique and unrepeatable character. That is why de Lubac can say that the community of the baptized, "the gathering of the children of the same mother, is a place of personal relations in the full sense of the word." ${ }^{112}$

According to the French theologian, the great threat of today is the invasion of the "impersonal reality" inside the Church, so that, for example, attempts are being made to replace personal mercy with structural charity and well understood collegiality with something similar to a party apparatus. ${ }^{113}$ These words undoubtedly stem from the observations made by the Lubac about the Church he lived in, in which these phenomena took place. Opposing them, he strongly emphasizes the personal character of the Church, which brings no ideology, but enables man to meet the Person of Jesus Christ, through whom he is also perfected in his personhood. ${ }^{114}$ It is thanks to the Church that we have fathers, brothers, and a Mother, and through it we experience the openness "upwards," which means that we are not suffocated by the tyranny of bureaucracy and mechanization, but we can breathe and live. ${ }^{115}$

At the end of his work, de Lubac signals that the motherhood of the Church is an "image" and an "effective symbol" of the maternal aspect of God Himself"16. This

110 MT, 196.

111 In MT, 197, footnote 2, de Lubac refers to the Church as the pleroma-plenitude of Christ, an idea which he finds in Ephesians and Colossians, and in his contemporaries such as Pierre Teilhard de Chardin and Louis Bouyer.

112 MT, 211.

113 MT, 228.

114 Cf. MT, 219.

115 Cf. MT, 221-222.

116 "Let the day come when we can all recognize in the motherhood of our Church an image or even an effective symbol of this Love, which the poet is not afraid to call God's motherhood: < Have mercy on me, 
remark brings to mind Eastern speculation on the subject of God's Wisdom, "uncreated Sophia." ${ }^{117}$ Parallels can also be found in Western theology, although with clearly eastern inspirations. For example, Marie-Joseph Le Guillou pointed to the Holy Spirit as a maternal aspect in God, totally dependent on God's fatherhood. In his opinion, the Holy Spirit is the source and exemplary cause of Mary's motherhood and the motherhood of the Church. ${ }^{118}$ The relationship between the Holy Spirit, the Church and Mary was similarly seen by the Polish Jesuit Jacek Bolewski in his original "sophio-Mariological synthesis." ${ }^{19}$ The juxtaposition with other works of de Lubac analyzed in this study, however, makes us see the sources of the Church's motherhood primarily in its "mystical identification" with the Mother of God. The Church is a person, a Mother, because the mystery of that person who is Mother of the Lord and Mother of all believers lives in her.

\section{Conclusion}

1. In this study, an attempt was made to extract from the works of Henri de Lubac the threads associated with broadly understood "sophiology" - that is, such a treatment of the relationship between the Creator and the creation that combines the biblical symbol of God's Wisdom, Mariology, ecclesiology and femininity.

2. The author of Catholicism, concerned about showing the unity of all stages of the history of salvation, understands this history as a development in time of a spousal relationships between the Creator and His creation. In this relationship, all initiative and creative power belong to the Bridegroom, but also the bride - in her subsequent forms - is called to active cooperation.

3. "Bride" is another name for creation, emphasizing its receptive, life-giving and unifying nature and its natural openness to God (capax Dei). Although this aspect of being, identified with biblical Wisdom, was already present at the very beginning - in the silent depths of the inanimate universe - it manifests itself with special power in human nature, called to unite with God in divine-human synergy.

4. Creation as a counterpart ot the Creator is multiple. Its essence, hidden behind the subsequent forms it adopts, does not reveal itself, in the inanimate matter present at the beginning of time, but in the One who crowns its transformations:

Lord / in the viscera of Your motherhood / because I know that your love for me / is like a mother's love in a new puerperium," MT, 228-229 (the quotation comes from a poem by Paul Claudel).

117 Cf. Philips, "Marie et l'Église," 413-414.

118 Cf. Richi Alberti, Teología del misterio, 190.

119 Bolewski, Misterium Mądrości, 285-290. On the same issue cf. also Evdokimov, La femme et le salut du monde, 215-216. 
Mary, Mother of God, at the same time a concrete person and "universal creation." Forever united to the work of her Son, "in whom everything was created" (Col 1:16), the Mother of God personifies the interaction of the creation with the Creator and reveals its true dignity. It is because of her, the biblical "Woman," that creation can be called the "eternal feminine."

5. This feminine dimension of created reality finds in Mary its explanation and its fullness, and from her it stretches to the Church-Ecclesia, which in its deepest essence (though not in its variable structures) is simply the shape that the creation is to assume after reaching the divinisation - the union with God in Christ. The Church, created on the model of Virgin Mary, is God's bride who will forever celebrate her wedding with the Beloved.

6. The perfect union of the Creator and the creation is the end of the evolution of the created universe. This does not mean, however, that what awaits the creation in the end is its dissolution in God, an apocatastasis, return to undifferentiated unity. On the contrary, it will exist forever, in unity without confusion, as the bride whom the Lord "created in the beginning" and which "will never cease to exist" (Sir 24,9).

\section{Bibliography}

Arjakovsky, A., "The Sophiology of Father Sergius Bulgakov and Contemporary Western Theology," St Vladimir's Theological Quarterly 49/1-2 (2005) 219-235.

Balthasar von, H.U., Herrlichkeit. Fächer der Stile. II. Laikale Stile (Einsiedeln: Johannes Verlag 1969).

Balthasar von, H.U., "Maryjny rys Kościoła," Balthasar von, H.U., Ratzinger, J., Maryja w tajemnicy Kościoła (Kraków: WAM 2007) 111-128.

Bolewski, J., Misterium Mądrości: traktat sofio-mariologiczny (Kraków: WAM 2012).

Bułgakow, S., Światło wieczności. Medytacje i spekulacje (Kęty: Wydawnictwo Marek Derewiecki 2010).

Evdokimov, P., La femme et le salut du monde: étude d’anthropologie chrétienne sur les charismes de la femme (Paris: Casterman 1958).

John Paul II, Letter to Women (1995), http://www.vatican.va/content/john-paul-ii/en/letters/1995/documents/hf_jp-ii_let_29061995_women.html.

Kerr, F., Twentieth-Century Catholic Theologians: From Neoscholasticism to Nuptial Mysticism, (Malden, MA: Blackwell 2007).

Lemna, K., "Louis Bouyer's Sophiology: a Balthasarian Retrieval," Heythrop Journal LII 52 (2011) 628-642.

Lévy, A., "Sophiologie," Dictionnaire critique de théologie (Paris: Quadrige/PUF 2013), 1343-1344.

Loades, A., "Théologie féministe," Dictionnaire critique de théologie (Paris: Quadrige/PUF 2013), 558-559. 
de Lubac, H., L'Éternel féminin: étude sur un texte du père Teilhard de Chardin. Suiv. de Teilhard et notre temps (Paris: Aubier Montaigne 1968) (=EF).

de Lubac, H., "La maternité de l'Église," idem, Les églises particulières dans L'Église universelle suivi de La maternité de l'église et d'une interview recueillie par G. Jarczyk (Paris: Aubier 1971) (= MT).

de Lubac, H., Méditation sur l'Église (Paris: Aubier 1953) (=ME).

de Lubac, H., Mémoire sur l'occasion de mes écrits (Paris: Cerf 2006).

de Lubac, H., Le mystère du surnaturel (Paris: Cerf 2000).

de Lubac, H., Paradoxe et mystère de l'Église (Paris: Cerf 2010) (= PME).

de Lubac, H., La pensée religieuse du père Pierre Teilhard de Chardin (Paris: Cerf 2002).

Milbank, J., The Suspended Middle. Henri de Lubac and the Debate concerning the Supernatural (Grand Rapids, MI - Cambridge, UK: Eerdmans 2005).

Nicolas, M.-J., "La doctrine mariale et la théologie chrétienne de la femme," Maria. Études sur la Sainte Vierge (red. H. du Manoir) (Paris: Beauchesne 1964) VII, 341-362.

Philips, G., "Marie et l'Église," Maria. Études sur la Sainte Vierge (red. H. du Manoir) (Paris: Beauchesne 1964) VII, 363-420.

Pié-Ninot, S., La teología fundamental (Salamanca: Secretariado Trinitario 2002).

Raczyński-Rożek, M., "Analogia Entis Ericha Przywary jako model myślenia katolickiego w postmodernistycznej rzeczywistości," Teologia w Polsce 12/2 (2018) 215-231.

Rahner, H., Maria und die Kirche: Zehn Kapitel über das geistliche Leben (Innsbruck: Marianischer Verlag 1951).

Ratzinger, J., “Miejsce mariologii i pobożności maryjnej w całości wiary i teologii,” H.U. von Balthasar - J. Ratzinger, Maryja w tajemnicy Kościoła (Kraków: WAM 2007) 15-30.

Ratzinger, J., "Znak niewiasty. Wprowadzenie do encykliki Redemptoris Mater," H.U. von Balthasar - J. Ratzinger, Maryja w tajemnicy Kościoła (Kraków: WAM 2007) 31-52.

Richi Alberti, G., Teología del misterio. El pensamiento teológico de Marie-Joseph Le Gouillou O.P. (Madrid: Encuentro 2000).

Shanley, B. J., The Thomist Tradition (Dordrecht - Boston, MA: Kluwer Academic Publishers 2002).

Špidlík, T., Myśl rosyjska. Inna wizja człowieka (Warszawa: Wydawnictwo Księży Marianów 2000).

Wagner, J.-P., Henri de Lubac (Paris: Cerf 2001). 
